Costume et déguisement dans le théâtre de Shakespeare et de ses contemporains

\title{
Veiling an Indian Beauty: Shakespeare and the hijab (2/2)
}

\section{Richard Wilson}

\section{(2) OpenEdition Journals}

Electronic version

URL: http://journals.openedition.org/shakespeare/1483

DOI: $10.4000 /$ shakespeare.1483

ISSN: 2271-6424

Publisher

Société Française Shakespeare

Printed version

Date of publication: 20 December 2008

ISBN: 2-9521475-5-8

Electronic reference

Richard Wilson, "Veiling an Indian Beauty: Shakespeare and the hijab (2/2)», Actes des congrès de la Société française Shakespeare [Online], 26 | 2008, Online since 20 December 2008, connection on 19 April 2019. URL : http://journals.openedition.org/shakespeare/1483 ; DOI : 10.4000/ shakespeare.1483 


\section{Costume et déguisement dans le théâtre de Shakespeare et de ses contemporains}

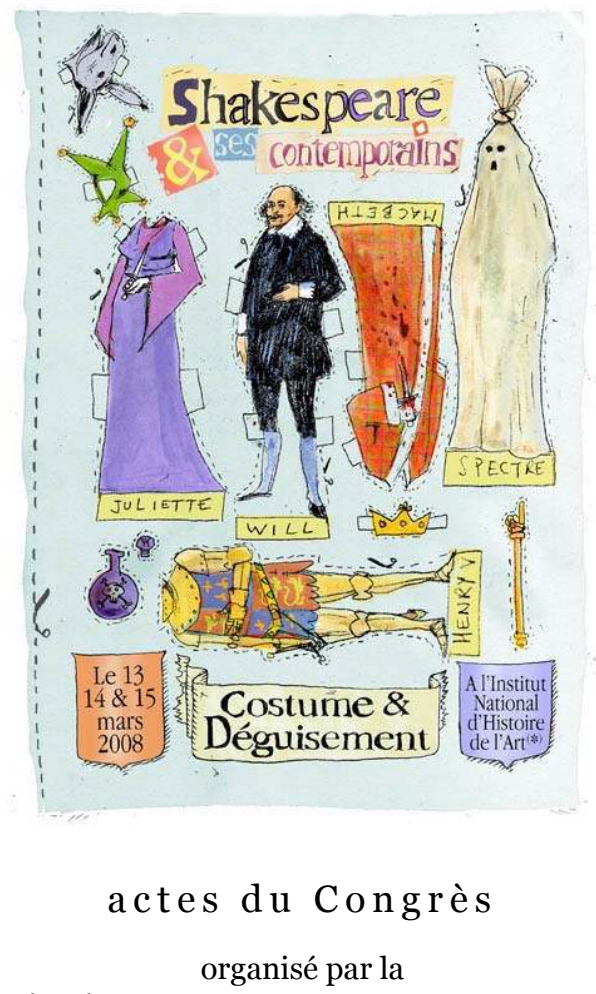

SOCIÉTÉ FRANÇAISE SHAKESPEARE

les 13,14 et 15 mars 2008

textes réunis par

Pierre KAPITANIAK

sous la direction de

Jean-Michel DÉPRATS 
COUVERTURE :

Edouard Lekston,

William en carton et ses habits à découper, 2008 edlek@free.fr

conception graphique et logo

Pierre Kapitaniak

\section{(C) 2008 Société Française Shakespeare}

Institut du Monde Anglophone

Université de Paris III - Sorbonne Nouvelle

5 rue de l'École de Médecine

75006 Paris

www.societefrancaiseshakespeare.org

Tous droits de traduction, de reproduction et d'adaptation réservés pour tous les pays 


\title{
VEILING AN INDIAN BEAUTY: SHAKESPEARE AND THE HIJAB
}

\author{
Richard WILSON
}

\author{
Thus ornament is but the guilèd shore \\ To a most dangerous sea, the beauteous scarf \\ Veiling an Indian beauty; in a word, \\ The seeming truth which cunning times put on \\ To entrap the wisest. \\ The Merchant of Venice (III.ii.97-101)
}

assanio's suspicion of the beauteous scarf / Veiling an Indian beauty' as an object of both danger and desire appears to explain why in The Merchant of Venice he prefers the casket of 'meagre lead' to 'pale and common' silver or 'gaudy gold.' This reverse Epiphany seems to belong to an Orientalist tradition in which the Muslim hijab alternates as a symbol of either eroticism or violence. Devised, perhaps, for Shrovetide, the 'casket scene' thereby typifies Carnival aggression, with its three guests no longer gift-bearing kings but recipients of their host's discrimination. ${ }^{1}$ So Bassanio's rejection of ornament plays to the prejudice of Portia's test, which ends when 'The curtain is drawn aside' $(S D: 1 ; 101)$, and a true European beauty is disclosed with the same eye-to-eye logic as that with which the Duke orders Shylock to 'stand before our face' (IV.i.15). For all their love of masks these Christians long for the face-to-face openness of a gift culture fast being destroyed by the self-interest for which a Jewish

\footnotetext{
${ }^{1}$ The Revels accounts record two performances of The Merchant of Venice during Shrovetide 1605, the second commanded by King James himself. For the Carnival connections, see Chris Hassel, Renaissance Drama and the English Church Year (Lincoln: Nebraska University Press, 1979), pp. 113-18. For a recent discussion of the ambiguity of the veil as a sign of both eroticism and violence, see Faegheh Shirazi, The Veil Unveiled: The Hijab in Modern Culture (Gainesville: University of Florida Press, 2001). But for a proposed emendation of Bassanio's lines, see Lisa Hopkins, “An Indian Beauty?" A Proposed Emendation to The Merchant of Venice,' Shakespeare New sletter, 50 (2000), 27. Hopkins argues for a punctuation of the lines as the beauteous scarf / Veiling an Indian; beauty - in a word, / The seeming truth... But this emendation diminishes the Orientalist 'dark lady' metaphor.
} 
banker can be blamed. Discovered inside the lead, 'Portia's counterfeit' is thus a miniature, with hair woven in 'A golden mesh,' to publicise rather than hide what this 'fairest creature northward born' claims: 'You see me, Lord Bassanio, where I stand, such as I am' (II.i.4; III.ii.115, 149). In masques ladies of the English court were likewise draped in veils of such transparent gauze their identity was never in doubt. Yet here the travel conceit with which Bassanio envisages the hijab veiling a 'dangerous sea' reminds us how to play this guessing game he has availed himself of a veil similar to that of the Indian houri, the 'over-weather'd ribs and ragged sails' of his infatuated Antonio's 'scarfèd barque,' now 'Vailing her hightop lower than her ribs,' as the effeminised merchantman is 'Hugged and embraced' only to be 'rent and beggared by the strumpet wind' (I.i.28; II.vi.14-19). And what the similarity of sails to veils reveals is the rub that this belly-dancing trade is all in favour of the East. As Ros Ballaster explains in Fabulous Orients, a 'Dark Lady' discourse emerges at this time in which the veiled and hidden woman of the seraglio' embodies both the superficial softness of Indian commerce and its underlying danger, as the entire subcontinent comes to be understood as an emasculating harem: 'a kind of abyss,' in the report of Colbert's agent, 'for a great part of the gold and silver of the world, which finds many ways to enter there, and almost none to issue hence. ${ }^{2}$ So if the Muslim veil should be rent in this text, we are warned at the start, that 'dangerous sea' would expose these 'tradeful merchants' to the hidden violence of the 'dark lady,' and reveal the treachery of their own secret desires at a time when 'India's economy is still more productive... Europe's lead is limited to ships... [and] Europe imports Asian manufactures, not the reverse': ${ }^{3}$

\footnotetext{
2 Ros Ballaster, Fabulous Orients: Fictions of the East in England, 1662-1785 (Oxford: O.U.P., 2005), p. 18-19, 69, 89 \& 267-68; 'Letter to Lord Colbert,' quoted p 268. Cf. Lisa Jardine and Jerry Brotton, Global Interests: Renaissance Art Between East and West (London: Reaktion, 2000), p. 184-5: In the fifteenth and sixteenth centuries, East and West me on much more equal terms... East met West in strenuous and constructive competition.' For the politically charged semiotics of silk, see also Roze Hentschell, Treasonous Textiles: Foreign Cloth and the Construction of Englishness,' Journal of Medieval and Early Modern Studies, 32 (2002), 543-70.

3 'Tradeful merchants': Edmund Spenser, Amoretti, 15:1; Philip Curtin, Cross-Cultural Trade in World History (Cambridge: C.U.P., 1984), p. 149. For the connection between the 'dark lady' conceit and colonial economic encounters, see also Kim Hall, Things of Darkness: Economies of Race and Gender in Early Modern England (Ithaca: Cornell University Press, 1995), p. 70-1 \& 80-1; and Joel Finemann, Shakespeare's Perjur'd Eye (Berkeley: University of California Press, 1986), p. 34
} 
Should I go to church

And see the holy edifice of stone

And not bethink me straight of dangerous rocks

Which, touching but my gentle vessel's side,

Would scatter all her spices on the stream,

Enrobe the roaring waters with my silks...

(Merchant, I.i.29-34)

If the 'beauteous' veil of Bassanio's 'dark lady' is some 'rich scarf' of silk (Tempest, IV.i.82), like those carried in the belly of Antonio's caravel, the confusion it causes repeats the thrill of illicit desire silk prompts throughout the plays, where a sensuous relish for the sheer sheen of the de luxe fabric cues disgust at the 'taffeta punk' (All's Well, II.ii.19), as opposed to 'russet yeas, and honest kersey noes' (Love's, v.ii.413), whenever 'simple truth' is 'abused / With silken, sly insinuating' lies (Richard III, I.iii.52). This association of 'changeable taffeta' (Twelfth, II.iv.75) with 'silken terms precise, / Three-piled hyperboles' (Love's, v.ii.406), was keyed to the inflated price of silk, not farmed in England until 1604 , when it cost 14 shillings a yard ${ }^{4}$ But it was the pliability of its soft fibre that also made it synonymous with the harem, as 'Silk could be spun into thread of varying thickness, and woven into fabric of different appearances, from finest gauze ("cyprus", "sarcenet", used in linings, and "tiffany", used for puffs), to taffeta, which was not so fine, velvet, plush (a deeper pile than velvet), and satin. ${ }^{5}$ Not for nothing was Shakespeare's father a glover, whose linings supplied a metaphor for linguistic duplicity - 'A sentence is but a cheverel glove to a good wit' (Twelfth, III.i.10-12) - and his Stratford friend Richard Quiney a draper selling taffeta, skeins of silk and silk buttons, as his texts flaunt appreciation of silk's versatility in all its varieties of 'sad cypress'

\footnotetext{
${ }^{4}$ Percy Macquoid, 'Costume,' in Shakespeare's England: An Account of the Life and Manners of his Age, ed. anon. (2 vols., Oxford: Clarendon Press, 1916), vol. 2, p. 101 . For more recent histories of fashion in early modern England, see John Brewer and Roy Porter, Consumption and the World of Goods (London: Routledge, 1993), pp. 274-301; Elizabeth Kowaleski-Wallace, Consuming Subjects: Women, Shopping, an Business in the Eighteenth Century (New York: Columbia University Press, 1997); Beverly Lemire, Dress, Culture, and Commerce: The English Clothing Trade Before the Factory, 1660-1800 (Basingstoke: Macmillan, 1997); Lena Orlin (ed.), Material London, ca. 1600 (Philadelphia: Philadelphia University Press, 2000); Daniel Roche, The Culture of Clothing: Dress and Fashion in the Ancien Regime, trans. Jean Birrell (Cambridge: C.U.P., 1994); Susan Vincent, Dressing the Elite: Clothes in Early Modern England (Oxford: Berg, 2003); and Lorna Weatherhill, Consumer Behaviour and Material Culture in Britain 1660-1760 (London: Routledge, 1996). For an important discussion of women and consumer society, see also Karen Newman, 'City Talk: Women and Commodification in Jonson's Epicoene,' English Literary History, 3 (1989), 503-18.

${ }^{5}$ Liza Picard, Elizabeth's London: Everyday Life in Elizabethan London (London: Weidenfeld \& Nicolson, 2003), p. 154.
} 
(Twelfth, II.iv.52), 'green sarcenet' (Troilus, v.i.26), 'flame-colour'd taffeta' (1Henry IV, I.ii.9), 'peach-colour'd satin,' or 'three-piled velvet' (Measure, I.ii.33; IV.iii.9). ${ }^{6}$ Indeed, with The Lodger Charles Nicholl situates the dramatist at the heart of London's silk industry, in the rooms he rented in the 1600 s from Christopher Mountjoy in Silver Street, Cripplegate, writing above the atelier where the French tiremaker operated the spinning wheels on which filaments of silk were twisted into thread known as 'sleaves,' which were then braided with wires upon other wheels to form the gold 'tissue' from which rose 'tires' or 'toys for the head' (Winter's, IV.iv.317). Trained in Crécy, long a centre like Arras for silk tapestry, Mountjoy was a master of the mystery of working such 'Venice gold' (Taming, II.i.346), the 'sweet commixture' (Love's, v.ii.296) of 'red and mingled damask' (As You, III.v.124) also named from Damascus, where the techniques of damascene 'cloth a' gold... lac'd with silver' (Ado, III.iv.19) had been developed. It was in Silver Street that Shakespeare doubtless saw the exorbitant workmanship of the bizarre 'ship-tire, the tire valiant, the tire of Venetian admittance' (Wives, III.iii.48), that literalised the veiled lady as a ship of war. So, though Nicholl peers into the Mountjoy house to catch the poet with Marie as his real 'Dark Lady,' the semiotic world of exotic textiles in which he asks us to imagine Shakespeare weaving his own texts to the rhythm of the loom is seductive enough to account for his hypersensitivity to the subtle secrecy of silk:

In one part of the shop an apprentice sits at a bench, drawing wires of gilded silver through die-holes to make the fine wire suitable for gold thread. There are hammers and rollers to flatten the wire into strips ready for spinning into thread. In another part of the shop bundles of raw silk are being separated into 'sleaves'. A third person is working the 'twisting wheel', turning those sleaves into silk thread, and silk thread into sparkling Venice gold... Metal fumes hang in the close air of the workshop, the smell of glues and dyes...Just outside... is a well-dressed gentleman of middle age who might be a merchant or mercer, but who is in fact the tiremaker's lodger... he is a shadow in the doorway, a footstep on the stairs... [but] what he sees and hears is stored away...to be used in turn as raw material in the manufacturing of metaphors... in "Sleep that knits up the ravelled sleave of care" (Macbeth, II.ii.36). ${ }^{7}$

\footnotetext{
${ }^{6}$ Edgar Fripp, Master Richard Quyny Bailiff of Stratford-upon-Avon and Friend of William Shakespeare (Oxford: O.U.P., 1924), pp. 83-4.

${ }^{7}$ Charles Nicholl, The Lodger: Shakespeare on Silver Street (London: Allen Lane, 2007), p. $164-5 \& 247$.
} 
For her own person, / It beggared description. She did lie / In her pavilion - cloth of gold, of tissue' (Antony, II.ii.203-5): Shakespeare's report of the voyage of the ultimate 'Dark Lady' echoes Marlowe, whose Dido likewise had galleons with 'tackling made of riven gold.' Both are seen as the tailors of the earth; comforting' their men that when old robes are worn out there are members to make new' (I.ii.149-50). But whereas the Queen of Carthage boasted 'sails of folded lawn,' the Egyptian surpasses linen with dyed 'purple sails' of 'silken tackle' which swell with 'touches of those flower-soft hands' $(199 ; 215) .{ }^{8}$ A whole crisis in European textile production lies behind this switch from wool to silk as the gold standard of economic prowess, a revolution Marlowe registered with his Jew of Malta's 'argosy from Alexandria...Laden with riches and exceeding store / Of Persian silks. ${ }^{9}$ And Fernand Braudel provided a global context for this ambiguous nexus of sails and veils swirling about a belligerent 'Indian beauty' when he noted how in the $1590 \mathrm{~s}$ almost every single letter from Venetian merchants carried some reference to silk,' and interpreted this fixation as an index of the insecurity when the value of bulk goods like English lead, tin and woollen textiles exported East was shamed by that of the silk, chintz and other light fabrics imported in return. ${ }^{10}$ Thus, there was 'a sort of super-demand' as 'the rich forsook gold and silver for silk, which as it became available to more people emerged as a symbol of social mobility' for a new consumer age. With the mass marketing of Indian, Persian and Chinese silks, Braudel recounted, "quick changes in fashion created artificial but imperative "needs" which might vanish overnight only to make way for other equally frivolous passions,' for while 'people still spun and wove at home,' the sudden availability of silk meant that it was now fashion and the luxury trade that dictated demand.' European governments legislated

\footnotetext{
${ }^{8}$ Christopher Marlowe, Dido Queen of Carthage, 3,1,115-124, in Christopher Marlowe: The Complete Plays, ed. Frank Romany and Robert Lindsey (London: Penguin, 2003), p. 31-2. For imagery of re-clothing in Dido Queen of Carthage, see Richard Wilson, Tragedy, patronage, and power,' in Patrick Cheney (ed.), The Cambridge Companion to Christopher Marlowe (Cambridge: C.U.P., 2004), p. 208-12.

${ }^{9}$ Christopher Marlowe, The Jew of Malta, 1,1,44-5;84-7, ibid. p. 251 \& 252.

10 Fernand Braudel, The Mediterranean in the Age of Philip II, trans. Siân Reynolds (London: Harper Collins, 1992), p. 402. For the London end of this transcontinental traffic, see in particular G.D. Ramsay, The Undoing of the Italian Mercantile Colony in Sixteenth Century London,' in N.B. Harte and K.G. Ponting (eds.), Textile History and Economic History: Essays in honour of Miss Julia de Lacy Mann (Manchester: Manchester University Press, 1973), p. 22-49, esp. p. 24
} 
to protect their textile industries from this invasion, Braudel related, 'but all in vain. Nothing worked,' not the banning of all Asian silks from England in 1700, nor the prize of 500 livres put up by Paris clothiers 'to strip any woman wearing Indian fabrics' naked in the street, or else to dress prostitutes in Indian silks and then undress them as examples. ${ }^{11}$ For while defenders of the sumptuary laws like Stubbes thundered that impudent insolvency is now grown that everyone, though very poor [...] will not stick to have silk,' the insatiable European demand for its soft, sleek, shimmering tissue ensured silk became what Bassanio makes it, and Troilus shows when he reminds the Trojans their 'breath bellied his sails' when Paris stole Helen, and 'We turn not back the silks upon the merchant / When we have spoiled them' (Troilus, II.ii.68-73), the superlative example of the object which generates its own desire:

Kate, eat apace; and now, my honey love,

Will we return unto my father's house,

And revel it as bravely as the best,

With silken coats, and caps, and golden rings,

With ruffs, and cuffs, and farthingales, and things,

With scarves, and fans, and double change of bravery,

With amber bracelets, beads, and all this knavery.

What, hast thou dined? The tailor stays thy leisure,

To deck thy body with his ruffling treasure.

(The Tam ing of the Shrew, IV.iii.52-60)

In Impersonations, his study of cross-dressing, Stephen Orgel notes the fetish allure of female apparel for Elizabethan males, their almost Lacanian awareness of the tendency of the imagination of a desirable thing to stir up the desire. ${ }^{12}$ And feminists notice how, in episodes such as Petruchio's cruel fort / da game with Kate's trousseau, where he scorns her choice of hat in kitchen terms as 'A custard coffin, a bauble, a silken pie' (82), Shakespeare's women shift from being producers or consumers of textiles to being identified with the cloth itself, a reification testifying how In early modern England it is the

\footnotetext{
${ }^{11}$ Fernand Braudel, The Wheels of Commerce: Civilization and Capitalism, $15^{\text {th }}-18^{\text {th }}$ Century, trans. Siân Reynolds (London: Collins, 1982), p. 178.

12 Stephen Orgel, Impersonations: The performance of gender in Shakespeare's England (Cambridge: C.U.P., 1996), p. 34-5; 'stir up the desire': John Rainoldes, The overthrow of stage plays (London: 1600), p. 97.
} 
material of subjectivity itself., ${ }^{13}$ Marina typifies them, weaving 'sleided silk' so adroitly 'Her inkle, silk, twin with the rubied cherry' (Pericles, $15: 21 ; 20: 8)$. Thus, as Bassanio's erotic object slides from the concealed face to its covering veil, the 'Indian beauty' Venetians crave, his travail imagery insists, is the cargo of 'silks' and 'spices' their 'argosies with portly sail' deliver from the 'dangerous' East (Merchant, I.i.9-31). Clearly, Shakespeare laughed to see the sails conceive / And grow bigbellied with the wanton wind,' when some freighter blown by the 'spicèd Indian air' travelled westward 'from a voyage, rich with merchandise.' There is a connection from the Latin velum retained in the French voile and voila, between veil and sail as opaque and open membranes, that enacts, Hélène Cixous and Jacques Derrida suggest in Veils, the infinite recession of veil and value, travail and travel, and self and silk: soi and soie. There can be no end in this serial homonymy to the Penelopean labour of 'unveiling as veiling. ${ }^{14}$ But in his dance of veils set in the capital of Carnival Shakespeare appears to fret over the travailing sailcloth as a figure Marking the embarkèd traders on the flood' (Dream, II.i.124-34) as emasculated by their veiled commerce with Muslims and Jews, and to be alerted by the likeness of their vessel's 'bellied sails' (Troilus, II.ii.74) to the Islamic hijab to wonder who in the end will prevail: those of other faiths who modestly refuse to 'thrust their head into the public street / To gaze on Christian fools with varnished faces' (Merchant, II.v.31), or these cross-dressed clowns who harass strangers with their masks. So, with his 'wisest' investors 'trapped' by their circuit of veiled Indian transactions, and the bonds of paper credit required to sustain it, Shakespeare appears to intuit what Patricia Fumerton analyses in her essay 'The Veil of Topicality,' that in masques such as Portia's alluding to this 'strange body' of overseas trade, Renaissance theatre was posing the crucial question for the private European self as it entered the global market of available identities and dangerous desires:

13 The material of subjectivity': Edith Snook, The Greatness in Good Clothes: Fashioning Subjectivity in Mary Wroth's Urania and Margaret Spencer's Account Book (BL. Add. MS 62092),' The Seventeenth Century, 22 (2007), 225-42, here 242. For the 'silencing' of women in this reification, see Susan Frye, 'Staging Women's Relations to Textiles in Othello and Cymbeline,' in Peter Erickson and Clark Hulse (eds.), Early Modern Visual Culture: Representation, Race, and Empire in Renaissance England (Philadelphia: University of Pennsylvania Press, 2000), pp. 215-50.

14 Jacques Derrida, 'A Silkworm of One's Own,' in Hélène Cixous and Jacques Derrida, Veils, trans. Geoffrey Bennington (Stanford: Stanford University Press, 2001), p. 39 \& 58. 
How to dress in ornaments the foreign trade and bourgeois barbarousness in which it was involved so as to sustain the fiction of gift culture while allowing business to continue as usual? How, that is, to dress up cannibals and bankers... so as to mask the fact that the "private" self was the embodiment of such greedy consumption? ${ }^{15}$

Nay, what are you, sir? O immortal gods, O fine villain, a silken doublet, a velvet hose, a scarlet cloak, and a copintank hat': though his father is 'a sailmaker in Bergamo,' in his silken garb Tranio imagines he passes for a gentleman (Shrew, v.i.54-65). As their own investment becomes global, Shakespeare's plays are alive to the reversal in world trade that disorients English gift culture in such ways, when the export economy grounded in European demand for English wool is inverted into an import economy fuelled by English consumption of 'ornamental' luxuries from Asia. Secreted by worms, silk is thus metonymic in these texts of the representational crisis as 'steel grows soft as the parasite's silk' (Coriolanus, I.ix.45). For in this panic about semblance and substitution sericulture is truly the medium of a serial betrayal. So while the ambassadors at the paradigm Field of the Cloth of Gold 'Make Britain India' in their silks, 'The clothiers...put off / The spinsters, carders, fullers, weavers, who...in desperate manner... are all in uproar' (Henry VIII, I.i.21; I.ii.32-7); and what enrages the clothier Jack Cade are 'silken-coated slaves' at court (2Henry VI, IV.ii.115). Poins's vice is therefore measured in 'peach coloured' silk stockings; and Hal's by 'new silk and old sack' (2Henry IV, I.ii.180; II.ii.14), until he leaves 'silken dalliance in the wardrobe' to raise 'silken streamers' (Henry V, Pro.II.2; Pro.III.6) against the French, themselves led by a 'cockered silken wanton' (John, v.ii.70). Likewise, Timon's flatterers 'wear silk, drink wine, lie soft' (Timon, IV.iii.206), as Cymbeline's fops are 'rustling in unpaid silk' (Cymbeline, III.iii.24). And for Antipholus of Syracuse the height of oriental devilry is when 'a tailor called me in his shop, / And showed me silks' (Comedy, IV.iii.6). Yet by the time of The Winter's Tale the inventory of Autolycus, the pedlar who swamps the sheep-shearing fair with imported 'lesser linen' like inkles, caddises, cambrics, ribbons of all colours,' wristbands, and 'golden coifs and stomachers,' registers the dramatist's own awareness not only of the commodity fetishism historians call 'The Great Reclothing' - the

\footnotetext{
${ }^{15}$ Patricia Fumerton, Cultural Aesthetics: Renaissance Literature and the Practice of Social Ornament (Chicago: Chicago University Press, 1991), p. 173.
} 
'bondage of certain ribbons and gloves' in a fashion system where 'You would think a smock a she-angel,' and they wear 'plackets where they should bear their faces' (IV.iv.202-15; 228-36) - but of the futility of fencing England's wool communities from the global market, given the universal availability of the new textiles shipped from Bengal, Ceylon, Madras or Persia by 'the miracle of long-distance trade. ${ }^{16}$ My traffic is sheets,' leers this 'Master Smooth, the silk man' (2Henry IV, II.i.29), advertising his pornographic chapbooks, made of coarse woollen bedding, as well as the luxury 'white sheet bleaching on the hedge' this cuckoo steals or sullies in return. But the 'fantastical' taste for modish oriental 'enfoldings' he passes on to his country customers to have them refashion themselves as 'gentlemen born' is as much a metropolitan makeover in this rag-to-riches tale of serial redressing as the sexual availability he proclaims:

Will you buy any tape,

Or lace for your cape,

My dainty duck, my dear-a?

Any silk, any thread,

Any toys for your head

Of the new'st and fin'st wear-a?'

(The Winter's Tale, IV.iv.318)

If you bargain with $\mathrm{Mr}$ Shakespeare, or receive money therefore, bring your money home if you may. I see how knit stockings be sold; there is great buying of them at Evesham': the only surviving letters naming Shakespeare place him in the thick of the Midland garment trade, as a backer of Quiney in a deal to make a killing in traditional knit hosings. ${ }^{17}$ Yet, like the itinerant pedlar who 'wore three-pile' velvet suits to serve Prince Florizel (IV.iii.5; IV.iv.710; v.ii.124); or indeed the dramatist himself, issued four and a half yards of scarlet cloth by the Master of the Wardrobe to parade as a Groom of the Chamber before King James; his actors acquired their cut-rate

\footnotetext{
16 Margaret Spufford, The Great Reclothing of Rural England: Petty Chapmen and the Wares in the Seventeenth Century (London: Hambledon Press, 1984), esp. pp. 88-105; 'miracle of overseas trade': Braudel, op. cit. (note 12), pp. 582-601; for penetration of rural England, see p. 64-7; cf. Walter Cohen, The undiscovered country: Shakespeare and mercantile geography,' in Jean Howard and Scott Shershow (eds.), Marxist Shakespeares (London; Routledge, 2001), p. 144.

${ }^{17}$ Abraham Sturley to Richard Quiney, October 30 1598, rpr. in E.K. Chambers, William Shakespeare: A Study of Facts and Problems (2 vols., Oxford: Clarendon Press, 1930), vol. 2, p. 102-3.
} 
wardrobe' of silk fabrics, we are told, second-hand from the court. ${ }^{18}$ This meant the players appeared in clothes that might actually have belonged to members of the audience;' but Anne Jones and Peter Stallybrass deduce that by re-cycling hand-downs the stage also became a catwalk for crowds to copy, a theory substantiated when the Commoners elbow into Julius Caesar in best apparel' (I.i.8). ${ }^{19}$ Shakespeare's early plays turn on cast-offs fitting 'As if the garment had been meant for me,' as Julia's says (Two Gents, IV.iv.155). But his later plays amplify the elite alarm over the self-fashioning available when, as Stubbes fumed, 'all persons dress indiscriminately in silks, velvets, satins, damasks, and taffetas,' as they also echo the actors' anxiety that 'our strange garments cleave not to their mould. ${ }^{20}$ The link between usurpation and the upstart whose expensive borrowed clothes 'Hang loose about him like a giant's robe / Upon a dwarfish thief' (Macbeth, I.iii.143; v.ii.21-2) is clinched in The Tempest, where Caliban's rebellion ends in a 'frippery' or second-hand shop, before Prospero himself disowns as 'trumpery' the 'rich garments, linens, stuffs,' that are the emblems of his power (I.ii.164; IV.i.186; 224]. So, of 70 instances in Shakespeare of the word 'garment,' 50 are in his Jacobean texts, with 15 in Cymbeline alone, the quick-change crossdressed drama that, as Stallybrass shows, questions more than any other the fetishizing of 'senseless linen' in a fashion system that judges a man by 'His mean'st garment' (I.iii.7; II.iii.128). ${ }^{21}$ I do not like the fashion of your garments,' Lear objects: 'You will say they are Persian; but let them be changed.' Poor Tom raves against 'the rustling of silks' himself. But the mad king's answer to 'gorgeous' oriental 'sophistication' is to 'unbutton' his 'lendings' and strip even 'looped and windowed raggedness' down to 'bare and unaccommodated' truth, so that Thou owest the worm no silk' (Lear, II.iv.269; III.iv.88-100;

\footnotetext{
18 Samuel Schoenbaum, William Shakespeare A Documentary Life (Oxford: O.U.P., 1975), p. 196; Stephen Greenblatt, 'Resonance and Wonder,' in Learning to Curse: Essays in Early Modern Culture (London: Routledge, 1990), p. 162.

${ }^{19}$ Stephen Greenblatt, Shakespearean Negotiations: The Circulation of Social Energy in Renaissance England (Oxford: Clarendon Press, 1988), p. 9; Anne Jones and Peter Stallybrass, Renaissance Clothes and the Materials of Memory (Cambridge: C.U.P., 2000). ${ }^{20}$ Philip Stubbes, quoted in Macquoid, op. cit. (note 5), p. 103.

${ }^{21}$ Peter Stallybrass, 'Worn worlds: clothes and identity on the Renaissance stage,' in Margreta de Grazia, Maureen Quilligan and Peter Stallybrass (eds.), Subject and object in Renaissance culture (Cambridge: C.U.P., 1996), p. 308-10. For the acquisition of clerical vestments by actors, see also Stephen Greenblatt, op. cit. (note 20), p. 112-14.
} 
III.vi.73). ${ }^{22}$ Christopher Hill thought the Quakers who streaked stark naked through London streets in the $1650 \mathrm{~s}$ were inspired by the nudism of King Lear. ${ }^{23}$ But 'the pedlar's silken treasury' (Winter, IV.iv.350] also supplies the solution English consumers preferred to such an apocalyptic divestment, which was to flaunt the availability of new textiles and front private desires with the public face of fashion itself:

Lawn as white as driven snow,

Cypress black as e'er was crow,

Gloves as sweet as damask roses,

Masks for faces, and for noses.

(The Winter's Tale, IV.iv.214-17)

Masks for faces, and for noses': Shakespeare's 'cloth-driven theatre' is quick to pick up on the strategy whereby Jacobean Londoners separated private faces from public spaces, which was to transport the face mask from fancy dress to the street. ${ }^{24}$ Stowe shuddered that 'Women's masks came into England about the time of the Massacre of Paris;' and Stubbes listed among obstacles to social order women riding with 'visors made of velvet wherewith they cover all their faces, having holes made in them against their eyes, wherewith they look. ${ }^{25}$ But about 1600 the drive to see and enjoy without being seen to enjoy took the form of silk 'masks for noses,' or black halfmasks known as vizards, covering only the upper face. Initially worn as accessories to protect the complexion, like the 'sun-expelling mask' Julia has discarded 'since she did neglect her looking-glass' (Two Gents, IV.iv.150), vizards were defined by John Cleveland in a 1647 poem, The King's Disguise,' as articles 'such as Ladies wear / When they are veiled on purpose to be seen.'26 Wycherley's Pinchwife will therefore miss the point when he exclaims such a visor 'makes people inquisitive and is as ridiculous a disguise as a stage-beard,' since

\footnotetext{
22 For Lear's suicidal mania for undressing, see Margreta de Grazia, The ideology of superfluous things: King Lear as period piece,' in de Grazia, Quilligan and Stallybrass, op. cit. (note 22$)$, p. 24-5.

23 Christopher Hill, The World Turned Upside Down: Radical Ideas During the English Revolution (Harmondsworth: Penguin, 1975), p. 279.

24 'Cloth-driven theatre': Stallybrass, op. cit (note 22), p. 300.

$25 \mathrm{~J}$ ohn Stowe quoted in M. Channing Linthicum, Costume in the Drama of Shakespeare and his Contemporaries (Oxford: Clarendon Press, 1936), p. 271-2; Philip Stubbes, The Anatomy of Abuses (London: 1583), sig. G.2.

26 John Cleveland, 'The King's Disguise,' in The Character of a London-Diurnal: With several select Poems (London: 1647), p. 33.
} 
according to Christoph Heyl in Masquerade and Identities, this virtual disguise was in fact designed to be penetrated: it was still easy to recognise the wearer... But this must have been sufficient to introduce new opportunities for playing with anonymity,' as these street masks 'both obscure their wearers and attract attention.' Heyl therefore views the vogue for half-masks in the 1600 s as a version of incognito ritual, in which, if you signal you are invisible, people who recognise you are constrained to behave as if you are unknown, a performance of suspended disbelief which can be compared to the theatrical aside. As Heyl remarks, the vizard thus negotiated a separation of public and private spheres by turning its wearer into an outsider 'in quotes': a hazardous bluff in the face-to-face community where a stranger was either hosted or expelled, but a knowing wink of mutual complicity in the urban metropolis 'populated by people who were and remained strangers to one another,' yet who were 'more at ease with anonymity than ever before. ${ }^{27}$ It functioned, that is to say, according to the closet epistemology defined by D.A. Miller and Eve Kosofsky Sedgwick as the practice whereby 'oppositions between public/private, inside/outside, subject/object are established' on the tacit understanding that 'we know perfectly well that the secret is known... nonetheless we must persist... in guarding it. ${ }^{28}$ So, 'Degree being vizarded,' as Shakespeare's Ulysses bemoans, The unworthiest shows as fairly in the mask' (Troilus, I.iii.83-4). Yet according to this analysis, the relaxation of such sexual, social, and religious discrimination was precisely the rationale of going 'veiled on purpose to be seen':

This apparently bizarre pattern of behaviour demonstrates that the privacy of strangers or of people who now wanted to be treated as strangers had become something to be respected... Something which would have been regarded as a masquerade in most other countries was here being taken for granted as a part of everyday life. This points to a

\footnotetext{
${ }^{27}$ Christoph Heyl, The Metamorphosis of the Mask in Seventeenth- and EighteenthCentury London,' in Efrat Tseëlon (ed.), Masquerade and Identities: Essays on Gender, Sexuality and Marginality (London: Routledge, 2001), p. 114-34, here pp. p. 119-20 \& 128. This important essay is reprinted as 'When they are veyl'd on purpose to be seen,' in Joanne Entwhistle and Elizabeth Wilson, Body Dressing (Oxford: Berg, 2005), p. 121-42.

28 D.A, Miller, 'Secret Subjects, Open Secrets,' in The Novel and the Police (Berkeley: University of California Press, 1988), p. 192-220, here pp. 195 \& 207. Cf. Eve Kosofsky Sedgwick, The Epistem ology of the Closet (Berkeley: University of California Press, 1990).
} 
level of tolerance in urban English society which was indeed remarkable. ${ }^{29}$

My visor is Philemon's roof. Within the house is Jove,' explains Don Pedro (Much Ado, II.i.80), alluding to the theme of the King and the Beggar that provided a pretext for the live-and-let-live rule practised by Charles II, his uncle Christian IV, and his grandfather Henri IV, in their escapades of clowning with the poor. The jest hints how even in the masquerades of his Elizabethan plays Shakespeare was attuned to the coming era that would depend not on revelation and unveiling but on what the Spaniard Don Armado learns is better than wars of religion: a discrete veil drawn over Most maculate thoughts... masked under such colours' (Love's, I.ii.83). Of course, no one was fooled by the emperor's new clothes when the Merry Monarch went slumming with Nell Gwyn, his uncle slipped unheralded into London under the pseudonym of Captain Frederickson, or his grandfather, dressed as a 'whistling' doorman, swept the stage at the Louvre to 'make place for the rascal players.' Henri took dressing down so far Louis XIII joked you could always tell his father by his stench. ${ }^{30}$ And New Historicism has seen through Prince Hal's 'veil of wildness' (Henry V, I.i.65). Their peasant togs enact the same fausse naïveté as those court dresses 'distressed' by 'slashing' to look 'new-fangled ill' (Sonnet 91), an artful imposture Petruchio demolishes the instant he glimpses his wife's ball-gown: 'O, mercy God, what masquing stuff is here?... Here's snip, and nip, and cut, and slish and slash, / Like to a scissor in a barber's shop' (Taming, IV.iii.87-91). ${ }^{31}$ Yet Anne Barton stresses how the popularity of the 'disguised king' genre symbolized the fantasy of 'harmony, good fellowship, and mutual understanding,' which was now replacing face-to-face dissent. ${ }^{32}$ And when Rosaline mocks that visor, that superfluous case, / That hid the worse and

\footnotetext{
${ }^{29}$ Heyl, op. cit. (note 28), p. 119 \& 128.

30 John Gade, Christian IV King of Denmark and Norway: A Picture of the Seventeenth Century (London: Cassell, 1928), p. 80-4; Leeds Barroll, Anna of Denmark, Queen of England: A Cultural Biography (Philadelphia: University of Pennsylvania Press, 2001), p. 143; Sir Robert Dallington (1604), quoted in Desmond Seward, The First Bourbon: Henry IV, King of France and Navarre (London: Constable, 1971), p. 164.

${ }^{31}$ For the slashing vogue, which peaked at the time of Shakespeare's romances, see Aileen Ribeiro, Fashion and Fiction: Dress in Art and Literature in Stuart England (New Haven: Yale University Press, 2005), p. 32-3.

32 Anne Barton, 'The king disguised: Shakespeare's Henry $V$ and the comical history,' in Essays, Mainly Shakespearean (Cambridge: C.U.P., 1994), p. 212.
} 
showed the better face,' Navarre has no need to regret that 'We were descried'(Love's, v.ii.387-9), for what these exchanges likewise prove is the immunity granted by the incognito rule. Francois Laroque has analysed the interplay of light and dark, vision and blindness, in the masquerade in Romeo and Juliet. ${ }^{33}$ But Ronald Knowles points out that Shakespeare changed the story of his lovers' meeting, which in the source occurs when 'All did unmask,' because 'for Romeo to have ummasked would have cancelled the hospitality' he exploits. ${ }^{34}$ Thus it is eye to eye contact which here remains taboo. As Capulet affirms when Romeo asks for 'a case to put my visage in,' and dons 'A visor for a visor' to gatecrash the ball, certain that whatever 'curious eye doth quote deformity, / Here are the beetle brows shall blush for me', the virtue of going 'covered with an antic face' for this scopic regime is not so much the release from identity it confers on the wearer, as the blind eye of obliviousness it demands of the viewer whenever some spoilsport Tybalt guesses the underlying truth (I.iv.29-32; I.v.53):

Content thee, gentle coz, leave him alone.
A bears him like a portly gentleman,
And, truth to say, Verona brags of him
To be a virtuous and well-governed youth.
I would not for the wealth of all this town
Here in my house do him disparagement.
Therefore be patient, take no note of him.

(Romeo and Juliet, I.v.62-6)

'To be in a mask bringeth with it a certain liberty and licence,' theorised Castiglione, 'and if he were in a mask and though it were so all men knew him, it skilleth not. ${ }^{35}$ The Latin for mask, persona, meant that Roman law took a mask at face value; and the idea of persona as personality licensed Medieval mumming, which assumed a 'vizard serveth to small effect when the Mummer is known. ${ }^{36}$ But as Meg Twycross explains in Masks and Masking, when Duke Ercole of

\footnotetext{
33 Francois Laroque, "Cover'd with an antic face": Les masques de la lumière et de l'ombre dans Romeo and Juliet,'Études Anglaises, 45 (1992), 385-95.

${ }^{34}$ Ronald Knowles, 'Carnival and Death in Romeo and Juliet,' in Ronald Knowles (ed.), Shakespeare and Carnival: After Bakhtin (Basingstoke: Macmillan, 1998), p. 44; Geoffrey Bullough, Narrative and Dramatic Sources of Shakespeare (7 vols., London: Routledge and Kegan Paul, 1964), vol. 1, p. 290.

35 Baldassare Castiglione, The Book of the Courtier, trans. Thomas Hoby, ed. J.H. Whitfield (London: Dent, 1974), p. 99-100 \& 105

36 Jacques Yver, Le Printemps d'Iver (Paris: Jean Ruelle, 1572), p. 202.
} 
Ferrara went guising at New Year, looking for egg-fights and erotic trysts, the blurring of social categories depended on the presence of the masker's identity.' Now 'the importance of masking is, and is acknowledged to be, a game' of both give and take. ${ }^{37}$ This is the kind of moratorium which gives Henry VIII its nervous rictus, when taking their cue from his disguise as a shepherd at Wolsey's ball, his victims humour the king by pretending not to recognise the 'one amongst 'em' (I.iv.81) who has power. So it is significant that whenever Shakespeare includes such guising he stretches the rules of this reverse blind-man's bluff, like London 'geezers' taking liberties by wearing their vizards around town. He tests the limits of mutual toleration: either to destruction, as when Romeo and Juliet fail to make their masked encounter last, or to triumph, as when the Princess and her Ladies put Navarre and his Lords to such shame that they must 'ever but in visors show their faces' (Love's, v.ii.271). Whatever the outcome, this change in focus from display to concealment reflects a new development in the mask-face relation, 'deliberately flirting with identity that is teasingly hidden but now never quite denied. ${ }^{38}$ The shift was from Elizabeth's belief in princes 'set on stages in the sight and view of all the world,' to James's paranoia that 'all the beholders' were 'bent to look and pry' into his 'secretest drifts. ${ }^{39}$ And so, even as the court masques were illuminating the Apollonian perspective of spectacular power - when the 'deep truth about the monarchy' was unveiled, in Orgel's words, as 'the fiction opened outward to include the whole court' - Shakespeare was devising a contrary form of theatre, in which a king's desire to pass at night veiled as 'a common man' is matched, as the soldier Williams reminds King Harry, by a subject's equally available new privilege to speak in private without giving offence: ${ }^{40}$

\footnotetext{
${ }^{37}$ Meg Twycross and Susan Carpenter, Masks and Masking in Medieval and Tudor England (Aldershot: Ashgate, 2002), p. $61 \& 67-8$.

38 Ibid., p. 188.

${ }^{39}$ Elizabeth I and James VI and I quoted in Christopher Pye, The Sovereign, the Theater, and the Kingdome of Darknesse: Hobbes and the Spectacle of Power,' in Stephen Greenblatt (ed.), Representing the English Renaissance (Berkeley: University of California Press, 1988), p. 279

40 Stephen Orgel, The Illusion of Power: Political Theater in the English Renaissance (Berkeley: University of California Press, 1975), p. 39. For the Apollonian optic of the court, see also Martin Jay, Downcast Eyes: The Denigration of Vision in Twentieth-Century French Thought (Berkeley: University of California Press, 1993), pp. 87-90.
} 
Your majesty came not like yourself. You appeared to me but as a common man. Witness the night, your garments, your lowliness. And what your highness suffered under that shape I beseech you take it for your own fault, and not mine for had you been as I took you for, I made no offence. (Henry V, IV.viii.47-50)

The King's first going abroad was privately to visit... his Houses, for naturally he did not love to be looked on': when James I toured his new capital 'secretly' in 1603, his cover was blown by the 'swarms' who shouted 'God save the King' to 'his great offence,' whenever he emerged into the street. ${ }^{41}$ Yet the fact that the sly ruler's peculiar desire for privacy was respected by those in the know may be connected to the virtual blind spot whereby, as Orgel points out, there are hardly any instances in which anyone sees through a disguise in English Renaissance drama,' for on this stage 'clothes really do make the man.'42 Thus, 'The soul of this man is in his clothes,' sniffs the old snob Lafeu of Paroles, the 'jack-an-apes with scarfs' who 'had the whole theoric of war in the knot of his scarf' (All's Well, III.v.85; IV.iii.138). 'A snipped-taffeta fellow' (IV.v.1), Paroles' identity really is bound up with his slashed 'scarves and bannerets': 'So, my good window of lattice,' Lafeu snipes, I look through thee' (II.iii.197-205); and 'You are undone, Captain - all but your scarf, that has a knot on't yet,' his captors sneer. But one of the twists which makes All's Well That Ends Well so unsettling is Paroles' determination that if a silk cravat is his undoing, 'Simply the thing I am / Shall make me live.' (IV.iv.300-11). His muffler has been so much a part of his old panache, when he does what Iago despises and wears his heart on his sleeve (Othello, I.i.64), that after he is blindfolded with it the 'saffron' drape (All's Well, IV.v.2) does seem a window into his soul. 'Muffled' (IV.iii.112) by the scarf that binds him, the man of words is therefore as much a victim as Malvolio, in his yellow stockings, of the constricting bondage of costume and interiority in the early modern fashion system, the tight fit between what Jones and Stallybrass call the superficiality of clothing and the depth of the superficial. $^{43}$ The clothes, in this view, make the man. Yet when he confesses, 'Captain I'll be no more' (308), what we glimpse in Paroles, as he unties that strangulating stock, is an inwardness not reducible to

\footnotetext{
${ }^{41}$ Sir Roger Wilbraham and Arthur Wilson, repr. in Robert Ashton, King James By His Contemporaries (London: Hutchinson, 1969), p. 62-4.

42 Stephen Orgel, op. cit (note 13), p. 102.

43 Jones and Stallybrass, op. cit. (note 20), p. 3
} 
such external matrices, a person behind the persona, or private face behind the public mask; as if in the weariness of All's Well That Ends Well, this pilgrim play about the travails of travelling, Shakespeare anticipated Derrida's boredom with the post-modern shibboleth of 'truth as a history of veils':

Voilà, fatigued like truth, exhausted from knowing it, for too long, that history of the veil, and all the folds, explications, complications, explicitations of its revelations and unveilings... when they are to do not only with opening onto this or that but onto the veil itself, a veil beneath the veil, like the thing itself to be buried...I am weary, weary, weary...of this opposition that is not an opposition, of revelation as veiling...Fed up with vails and sails. ${ }^{44}$

In All's Well Paroles' loosened scarf seems to flag his philosophy that 'There's place and means for every man alive' (IV.iv.316). Likewise, in Measure for Measure, Andrew Gurr writes, the old tag that 'Cucullus non facit monachum' - the cowl does not make the monk and that in adopting Franciscan habit the Duke is 'honest in nothing but his clothes,' ironises Angelo's criticism of 'these black masks' that Proclaim an enshield beauty ten times louder / Than beauty could be displayed': the visors worn by Isabella and Mariana at the close when Lucio 'pulls off the friar's hood and discovers the Duke' (II.iv.79-80; v.i.259; SD,347). Angelo reads such a visor as an incitement, like the mask Cressida carries, she smirks, 'to defend my beauty' (Troilus, I.ii.242), or the 'virtuous visor' the mother of Richard III fears hides 'deep vice' (Richard III, II.ii.28). But according to Gurr the separation of public and private spheres in this comedy depends on the very ambiguity when masked women are, as Posthumous rails, either for preservation cased, or shame' (Cymbeline, v.v.21). Here the Duke rejects Lucio's excuse that he spoke, like Williams, 'according to the trick' when he defamed him in private. But a play that spares its heroine the religious veil and the convent 'Isabella Rule' that if you speak, you must not show your face; / Or if you show your face you must not speak,' still ends having her wait behind a visor until the Duke offers her a 'destined livery' as his bride (I.iv.12; II.iv.138; v.i.498). Thus half-masks in Measure for Measure solve the problem

\footnotetext{
44 Derrida, op. cit. (note 15), pp. 38-9. See Katharine Eisaman Maus, Inwardness and Theater in the English Renaissance (Chicago: Chicago University Press, 1995), for a sustained critique of the idea that the individual derived sense of the self from external matrices'in Shakespearean England (p. 2).
} 
of finding a middle way between freedom and the law,' Gurr concludes, by shielding Isabella from male chicanery: 'Disguise becomes a means to everyone's uncasing,' as 'For the whole finale (we see) her dressed in a gentlewoman's face mask, with all the freedom it offered.' Hoods, masks, scarves and veils have received too little attention in Shakespeare studies, Gurr remarks. ${ }^{45}$ Yet whether or not the dramatist was familiar with the Poor Clares, or had a great-aunt Isabel who became a prioress, his comedy does seem to acknowledge the GrecoRoman, Byzantine, Hindu, and Islamic, as well as Catholic tradition that respects the veil as a sign of privilege and power. Measure for Measure dates from a time when nuns like Mary Ward were adjusting the veil to varying degrees of seclusion; as others, like the Venetian nuns whose transparent lace 'attracted rather than deflected the male gaze,' were testing how permeable convent walls, grilles, and doors could become. ${ }^{46}$ So in this drama the visor seems, like the modern hijab, a means to negotiate a sphere of social freedom. ${ }^{47}$ For once Isabella is fitted out in one of the fashionable silk half-masks of the 1600 s her enigmatic silence at the close is keyed to the epoch-marking phenomenon the play explores, the aversion to being studied by 'millions of false eyes' (IV.i.59) in the new metropolis where even the king now claimed 'safe discretion' for his own private desires and 'secretest drifts':

\footnotetext{
I love the people,

But do not like to stage me to their eyes.

Though it do well, I do not relish well

Their loud applause and aves vehement;

Nor do I think the man of safe discretion

That does affect it.
}

(Measure, I.i.67-72)

'Among all parts of the world, only England has not seen masked beasts,' reported Polydore Vergil in the $1490 \mathrm{~s}$, 'nor does it want to, because among the English...there is capital punishment for

\footnotetext{
45 Andrew Gurr, 'Measure for Measure's Hoods and Masks: The Duke, Isabella, and Liberty,' English Literary Renaissance, 27 (1997), 89-105, here 91 \& 102-3.

46 Jutta Gisela Sperling, Convents and the Body Politic in late Renaissance Venice (Chicago: Chicago University Press, 1999), p. 141. For Mary Ward and the debate about the clausura, see Elizabeth Rapley, The Dévotes: Women and Church in Seventeenth-Century France (Montreal: McGill-Queen's University Press, 1990), p. 28-9 \& 54-6.

47 John Bowen, Why the French Don't Like Headscarves: Islam, the State, and Public Sphere (Princeton: Princeton University Press, 2007), p. 71.
} 
anyone who wears masks. ${ }^{48}$ As an Italian migrant Vergil had reasons for exaggerating a London by-law against 'any feined beards, painted visors, disformed or coloured visages, in any wise. ${ }^{49}$ But the Tudor resistance to street masking, culminating in a 1511 Act outlawing any who 'disguised and apparelled' themselves, or 'covered their faces with Visors in such manner that they should not be known,' makes it even more striking that Shakespeare's stage revolves around the kind of 'mask'd and vizarded' imbroglio that brings The Merry Wives of Windsor to the boil, with 'vizors' for the children and a silk veil for the Queen of the Fairies (IV.vi.40). This is a theatre where, as Arden's 'hoodies' show, when they dress like Robin Hood and 'with a kind of umber smirch' their faces, those who 'outface it with their semblances' go 'To liberty, and not to banishment' (As You, I.iii.106-32). Equally noticeable, however, is that with the exception of Snug's Athenian lionmask, from the lady's vizard in which Flute plays Thisbe (Dream, I.ii.41) to the highwaymen's visors on visors that 'inmask' $\mathrm{Hal}$ and Poins (1Henry IV, I.ii.159), and the cagoules that 'mask' Caesar's assassins (Julius, II.i.73-81), what intrigues Shakespeare is not the 'absolute mask' of antiquity - the persona whose 'face is vizard-like, unchanging' (3Henry VI, I.iv.117) - but the tantalizing half-mask which, as Barthes writes, always teases us with 'the theme of the secret': as if in this game the mask is always inviting Falstaff's response: 'By the lord, I knew ye as well as he that made ye' (1Henry IV, II.v.246). ${ }^{50}$ As Jean-Luc Nancy comments, it is the very function of such a mask to draw attention to itself, since its paradox is a self-showing that withdraws. Monstration occurs in concealment, and from out of that concealment or disappearance. ${ }^{51}$ Thus for Heyl, the dialectical function of the vizard, as both repellent and invitation, is allied to the virtual disguise' of the literary pseudonym, as the kind of blind eye which was turned towards its open secret is essential to the 'strip-tease' of modern authorial anonymity. It may not therefore be chance that in the literary text which, from the instant the Ghost materialises with its beaver up'

\footnotetext{
48 Polydore Vergil, Beginnings and Discoveries: Polydore Vergil's De inventoribus rerum, trans. Beno Weiss and Louis Përez (Nieukoop: De Graaf, 1997), p. 329.

${ }^{49}$ Proclamation of 1418, London: Guildhall Letter Book I, folio 223r, quoted in Twycross, op. cit. (note 30$)$, p. 331 .

${ }^{50}$ Roland Barthes, 'The Face of Garbo,' in Mythologies, trans. Annette Lavers (London: Vintage, 1993), p. 56.

51 Jean-Luc Nancy, 'The Masked Imagination,' in The Ground of the Image, trans. Jeff Fort (New York: Fordham University Press, 2005), p. 96.
} 
(Ham let, I.iii.228), demonstrates more than any other the 'visor effect,' as Derrida terms it, by which 'we do not see who looks at us,' the occulted sense of secrecy is associated throughout with what Heyl maintains was a perception unique to early modern London, the revolutionary recognition that 'dress and outward appearance were no longer an infallible guide to status': 52

'Tis not alone my inky cloak, good mother,

Nor customary suits of solemn black...

That can denote me truly..

I have that within which passeth show,

These but the trappings and the suits of woe

(Hamlet, I.ii.78-86)

Hamlet's 'antic disposition' (I.v.72) might be seen as a supreme instance of the inky textual cloak as functional equivalent of the Jacobean black mask: a ruse that only 'pretends to disguise,' and instead of making one inconspicuous, makes onlookers more inquisitive. ${ }^{53}$ And in Secret Shakespeare I suggested such a 'masked imagination' relies on the same closet subjectivity as paintings by Caravaggio, where as Leo Bersani and Ulysse Dutoit observe, the invitation to interpret is its own concealment, for secrecy is here performed by a body 'at once presenting and withdrawing' its coy availability. Thus in Caravaggio's depictions of boys the homoerotic pose promotes unreadability into a "wilful reticence, as if we were being solicited by a desire determined to remain hidden. ${ }^{54}$ Putting secrecy on display, Caravaggio creates an inscrutability like that of the facemask, signalling 'Don't ask, don't tell'. It may not, then, be chance that Shakespeare's Carnival comedy opens trailing Antonio's tease, I know not why I am so sad,' a mystification critics decode, as they do the pictures, as nudging towards a love that dare not speak its name. For unlike masques, which unveil in the discovery scene that, as Orgel notes, is their most fragile point, by displacing illicit desires onto strangers, in this play the failure to scapegoat Shylock means those

\footnotetext{
52 'Visor effect': Jacques Derrida, Specters of Marx: The State of the Debt, the Work of Mourning, and the New International, trans. Peggy Kamuf (London: Routledge, 1994), p. 7; Heyl, op. cit, (note 28$)$, p. 128.

53 Ibid.

${ }^{54}$ Richard Wilson, Secret Shakespeare: studies in theatre, religion, and resistance (Manchester: Manchester University Press, 2004), p. 35 \& 298; Leo Bersani and Ulysse Dutoit, Caravaggio's Secrets (Cambridge: MIT Press, 1998), p. 8-9.
} 
'fools with varnished faces' can never unmask. ${ }^{55}$ So, while Bassanio thinks 'golden locks, / Which makes such wanton gambols with the wind,' wigs as false as prosthetic beards on boys, he calls his own gamble a quest for 'golden fleece,' and to marry gold fakes a beard of Hercules' himself (I.ii.170; III.ii.83-94). Here masculinity is fashioned, we see, like the 'livery' Lancelot exchanges for deserting the Jew, in distinction to the 'little scrubbed boy' who 'will ne'er wear hair on's face' (II.ii.139; v.i.157-61). ${ }^{56}$ While a happy ending to this game of open secrets also depends, as Orgel observes, on the 'startling pederastic fantasy' of girls 'turn(ing) (in)to men' (III.v.79), since these females are in reality boys 'The seeming truth' therefore disguises an even deeper untruth: that in these 'cunning times' of 'masked balls' there will be mask on mask and veil upon veil. ${ }^{57}$ For the last 'Indian beauty' to be the object of such passionate desire in both men and women, we remember, was indeed Oberon's mysterious but 'lovely... Indian boy' (Dream, II.i.22; III.ii.375). In this story Bassanio pretends to prefer Portia's 'golden mesh' to a 'beauteous scarf.' Yet in a reversal of her own entry test his bride will cross-dress and name herself after Balthazar, the black Magus who brings myrrh from the East. So perhaps Shakespeare heard how early modern European travellers to the subcontinent were surprised when the beguiling figure at a Muslim wedding who emerged wearing a golden veil, and with a silk handkerchief covering the mouth, turned out to be the groom. ${ }^{58}$

Mislike me not for my complexion, / The shadowed livery of the burnished sun' (II.i.1-2): as the only actual Muslim in The Merchant of Venice Morocco's plea that his skin is yet another mask gains a further coating of pathos if, as Patricia Parker infers, a 'Moorish' or 'Indian' complexion is 'shadowed livery' in Shakespeare for the 'tribe' of the

55 Stephen Orgel, The Jonsonian Masque (Cambridge, Mass.: Harvard University Press, 1967), p. 87-8.

${ }^{56}$ For beards as signifiers of masculinity, see Will Fraser, The Renaissance Beard: Masculinity in Early Modern England,'Renaissance Quarterly, 54 (2001), 155-87. But for the prosthetic construction of masculinity in false facial hair, see Mark Albert Johnston, 'Prosthetic Absence in Ben Jonson's Epicoene, The Alchemist, and Bartholomew Fair,' English Literary Renaissance, 37 (2007), 401-29.

57 Stephen Orgel, op. cit. (note 13), p. 77.

58 Meer Hassan Ali, Observations on the Mussulmauns of India Descriptive of their Manners, Customs, Habits and Religious Opinions (London: Humprey Milford \& O.U.P., 1832; repr. 1917), p. 204: The dress of the bridegroom is of gold-cloth, with an immense bunch of silver trimming that falls over his face, and answers to the purpose of a veil... and to his mouth he keeps a red silk handkerchief closely pressed to prevent devils entering.' 
martyred fool Thomas More: a rumour heard when he finds a momento mori preserved as if in myrrh inside the golden box. ${ }^{59}$ The black man,' as More was called, claimed descent from the negro Doge Moro on whom Shakespeare based Othello, so mounted an impaled blackamoor on his crest. Morocco's death's-head looks, then, to clinch a network of crypto-Catholic murmurs running, by way of Latin puns on That black word death' (Romeo, III.iii.27), from the mural concealing Thisbe to the sycamour Desdemona laments. What knits them all, Parker proposes, is Ovidian moralizing on the moro: the indelible mulberry darkened by the blood of Pyramus on which the silkworm feeds. Critics have long seen the silk handkerchief in Othello as 'more than just a symbol of marriage,' like 'wedding sheets' by 'lust's blood spotted,' for a play obsessed by 'lawn, gowns, petticoats... caps,' in which the heroine dies because her husband cannot trust the innocence of her fan, her gloves, her mask, nor nothing' (IV.i.105; IV.ii.10; IV.iii.72; V.i.44) ${ }^{60}$ But now we are assured the reasons why 'There's magic in the web of it' is that 'The worms were hallowed that did breed the silk' after feasting on the 'More tree'; that it has been 'dyed in mummy which the skilful / Conserved of maidens' hearts' like those of the Tudor martyrs; and that it was preserved by a Romany (III.iv.54-73), this morbid facecloth morphs into a relic beside veils like Veronica's, as a maudlin signifier of mourning for a proscribed religion, and so joins Thisbe's mantle - the original Indian veil, woven presumably by Bottom, the weaver named after a skein of silk - in a true sericulture of veiled effusions of shrouded grief. ${ }^{61}$ Being Venetians, these 'Christian fools in varnished faces' are, of course, themselves all of 'the tribe of More,' Morocco hints, when he begs them to acknowledge 'This thing of darkness' theirs (Tempest, 5,1,278). Shakespeare thus seems to predict the 'qualified intolerance' that allowed the English to 'judge without prejudice' the 'Agreement of the Customs of the Indians with those of the Jews,' in a nascent universalism that relativised Catholics under cover of a sense of

\footnotetext{
${ }^{59}$ Patricia Parker, 'What's in a Name: More,' Sederi XI: Revista de la Sociedad Española de Estudios Renacentistas Ingleses (Huelva: Universidad de Huelva Publicaciones, 2002), 101-49, esp. 131-5; Wilson, op. cit. (note 55), p. 155-85, esp. p. 178.

${ }^{60}$ Dympna Callaghan, Looking well to linens: women and cultural production in Othello and Shakespeare's England,' in Howard and Shershow, ibid, p. 61.

${ }^{61}$ For Thisbe's veil as a feature of a Babylonian love story and so the prototype of the hijab, see Shirazi, op.cit. (note 1), p. 3-4.
} 
'analogy, shared history, and sameness. ${ }^{62}$ As this overdetermined veil of topicality unfolds modern readers might find such a 'Moorish' subtext rebarbative, just as Morocco assumes we 'mislike' a coloured skin. The violent charisma of the veil means that it always presents itself in the form of such a challenge. But as Derrida reflects, as he ponders the warp and woof of his frayed Jewish tallith in his essay 'A Silkworm of One's Own,' however much a softer age might deplore it, we will never get to the bottomless bottom' of the history of violence which colours such 'a twist of rotten silk' (Coriolanus, v.vi.95):

I would like to sing the very solitary softness of my tallith, softness softer than softness, entirely singular...calm, acquiescent, a stranger to anything maudlin, to effusion or to pathos, in a word to all "Passion." And yet... before ever having worn a tallith or even dreamed of having my own, I cultivated... silkworms... In truth, they needed lots of mulberry, too much, always too much, these voracious little creatures... This philosophy of nature was for him, for the child I was but that I remain still, naiveté itself, doubtless, but also the time of infinite apprenticeship, the culture of the rag trade... (so) the word mulberry was never far from ripening and dying in him, the mulberry whose colour he warded off like everyone in the family, a whole history and war of religions. ${ }^{63}$

If you have tears, prepare to shed them now. / You all do know this mantle' (Julius, III.ii.164): Jones and Stallybrass consider all items of early modern clothing to be materials of memory: a 'second skin' which 'inscribed conflict' and had violence written into it, like the napkin embroidered with 'conceited characters' which the forlorn maid wrings in 'A Lover's Complaint': Laund'ring the silken figures in the brine.' 64 Thus, when Hero's wedding-dress is compared to the infamous gown of 'cloth o' gold, and cuts, and laced with silver, set with pearls, down sleeves, side sleeves, and skirts round underborne with a bluish tinsel,' worn by Mary Tudor in her role as 'Duchess of Milan' for her wedding to Philip of Spain (Much Ado, III.iv.14-19), the traces of

\footnotetext{
62 John Tolland, The Agreement of the Customs of the East Indians With Those of the Jew s and other Ancient People (London: 1705; repr. New York: AMS Press, 1999), p. ii; 'Qualified intolerance': Antony Milton, 'A Qualified Intolerance: The Limits and Ambiguities of Early Stuart Anti-Catholicism,' in Arthur Marotti, Catholicism and AntiCatholicism in Early Modern English Texts (Basingstoke: Macmillan, 1999), p. 105.

63 Derrida, op. cit. (note 15), p. 61, 84 \& 90-1.

64 Jones and Stallybrass, op. cit. (note 20), p. 32; 'shared history': Ballaster, op. cit. (note 2), p. 18.
} 
sectarian violence could not be more dark. ${ }^{65}$ But Shakespeare's texts string out a veritable washing-line of such mnemonic mantles, scarves, shawls, shrouds, veils, and vestments, all tear-soaked or matted in harmless blood' (3Henry VI, I.iv.80) - from the 'dishclout' Armado was 'enjoined in Rome' to wear 'next to his heart' (Love's, v.ii.696), to the popishly 'glistening apparel' hung out by Ariel to trap morons mourning 'Mistress Line' herself, the martyr Anne Line (Tempest, SD. IV.i.194; 233) - in which, as Celia exclaims of Orlando's bloodstained handkerchief, there is ever 'more in it' (As You, IV.iii.158). Shakespeare knows the martyr will always have devotees to 'dip their napkins in his sacred blood' (Julius, III.ii.130). Yet in episodes such as Antony's terroristic unveiling of Caesar's shroud, with the revelation of the 'place,' 'rent,' and 'unkindest cut' where 'the blood of Caesar followed,' we are alerted to the category confusion of idolizing the mantle muffling up his face' as if it was 'Caesar's vesture' that was 'wounded' (181-90): the 'strong madness in a silken thread' (Ado, v.i.25), for an age which has seen 'napkins enough' (Macbeth, II.iii.6). So, though Bianca fails to 'take out' the 'work' a 'sybil... In her prophetic fury sewed' into the Egyptian veil (Othello, III.iv.68-70; 174; IV.i.145), Greenblatt is surely right to say that Shakespeare's plays are haunted by religious signifiers which have been 'emptied out,' if by that evacuation we mean that their 'prophetic fury' has been laundered in the pacifying solution of theatre itself. ${ }^{66}$ His characters do indeed inhabit 'a worn world,' clad in second-hand cast-offs of the war of religions, which have been fabricated in Italy, from silk shipped out of Africa, bought in India with American gold ${ }^{67}$ But as the action of The Tempest suggests, his own work with veils and sails seems to be to wash out the blood and tears, so as to leave 'On their sustaining garments not a blemish, / But fresher than before'(I.ii.219-20):

our garments being, as they were, drenched in the sea, hold notwithstanding their freshness and glosses, being rather new-dyed than stained with salt water [...] as fresh as when we put them on first in Afric, at the marriage of the King's fair daughter Claribel to the King of Tunis. (The Tempest, II.i.62-70)

\footnotetext{
65 See Wilson, op. cit. (note 55), p. 96-7.

66 Greenblatt, op. cit. (note 20), p. 119 \& 126

67 'Worn world': Stallybrass, op. cit. (note 22).
} 
From Moslem, to Christian, to theatrical possession: 'What is at stake in the shift from the old religion' to theatre, asks Greenblatt, when 'a bit of red cloth' like Cardinal Wolsey's silk berretta is recycled on a stage that both 'mocks and celebrates' its violent charisma? ${ }^{68}$ The answer, Bassanio's 'Indian veil' suggests, is the separation of private and public spheres as a precondition of racial, religious, sexual, and artistic freedoms. Unseen to see those she feign would know,' the 'masked lady in the pit' at the playhouse was herself a contributor to this new coexistence, Gurr shows. ${ }^{69}$ And the 'Moorish' hieroglyphics of a text like the Masque of Blackness, acted by the Catholic Queen Anne in defiance of those who thought black faces a loathsome sight,' confirm how audiences would indeed penetrate Shakespeare's moral about his dark materials as he wove a tissue of terror and toleration out of a mortal 'thread of silk' (Dream, v.i.341). ${ }^{70}$ In episodes like the veiling of the 'Madonna' Olivia, when the 'dark lady' covers up with her mantilla so 'like a cloistress she will veiled walk,' these dramas do seem to stress the morbid danger of an interiority apt 'to take dust' like Mistress Mall's' (or Mary's) picture, curtained in the recusant house (Twelfth, I.i.27; I.v.43-137). The poet's own 'masked imagination' always hopes for some grand unveiling, like the discovery scenes that Prospero controls: The fringed curtains of thine eye advance / And say what thou seest yon' (Tempest, I.ii.412-13). But in our present standoff, this secretive Shakespeare assures us, the question of the hijab 'veiling an Indian beauty' must remain one of trust - as Alain Badiou similarly reflects: Brecht says that the end is with us when the figures of oppression no longer need masks,' but 'it is necessary to rethink the relation between violence and the mask... The theatrical mask is a symbol of a question erroneously designated in the century of the lie. The question is better formulated as follows: What is the relation between the passion for the real and the necessity of semblance? ${ }^{71}$ Or

\footnotetext{
68 Greenblatt, op. cit. (note 20), p. 161-3.

69 John Lane (1600) and 'T.M.' (c.1620), quoted in Andrew Gurr, Playgoing in Shakespeare's London (Cambridge: C.U.P., 1987), p. 66 \& 73.

70 'Very loathsome': Dudley Carleton, cited in C.H. Herford, and Percy and Evelyn Simpson, Ben Jonson (11 vols., Oxford: Clarendon Press, 1925-52), vol. 10, p. 449. For Anne's defiant 'drama of feminine blackness,' see also Sophie Tomlinson, 'Theatrical Vibrancy on the Caroline Court Stage,' in Clare McManus (ed.), Women and Culture at the Courts of the Stuart Queens (Basingstoke: Palgrave, 2003), p. 194-5.

${ }^{71}$ Alain Badiou, The Century, trans. Alberto Toscano (Cambridge: Polity Press, 2005), p. 47.
} 
as Derrida decides at the end of his essay on sails and veils, the secretion of the silkworm, this 'slime from slugs,' is the precious secret of the secret itself:

What I appropriated for myself... was the operation through which the worm itself secreted its secretion. It secreted it, the secretion... It secreted absolutely... this little silent finite life was doing nothing other...than this: preparing itself to hide itself, liking to hide itself, with a view to coming out and losing itself... wrapping itself in white night. ${ }^{72}$

Richard WILSON

University of Cardiff

72 Derrida, op. cit. (note 15), p. 89-90, 'slime from slugs': p. 91. 